\title{
Property rights imperfections and asset allocation: Co-ownership in Bulgaria
}

\author{
Liesbet Vranken $^{\mathrm{a}, \mathrm{b}}$, Karen Macours ${ }^{\mathrm{c}, \mathrm{d}, *}$, Nivelin $\operatorname{Noev}^{\mathrm{e}}$, Johan Swinnen ${ }^{\mathrm{a}, \mathrm{f}}$ \\ ${ }^{\text {a }}$ LICOS Center for Institutions and Economic Performance, Belgium \\ ${ }^{\mathrm{b}}$ Department of Earth and Environmental Sciences, University of Leuven (KUL), Belgium \\ ${ }^{\mathrm{c}}$ Paris School of Economics, France \\ ${ }^{\mathrm{d}}$ INRA, France \\ e European Commission, Belgium \\ ${ }^{\mathrm{f}}$ University of Leuven (KUL), Belgium
}

\section{A R T I C L E I N F O}

\section{Article history:}

Received 29 June 2009

Revised 3 October 2010

Available online 5 January 2011

\section{JEL classification:}

012

P26

P32

Q15

\section{Keywords:}

Property rights

Asset allocation

Land markets

\begin{abstract}
A B S T R A C T
Vranken, Liesbet, Macours, Karen, Noev, Nivelin, and Swinnen, Johan-Property rights imperfections and asset allocation: Co-ownership in Bulgaria

This paper analyzes how imperfections of property rights affect households' allocation of assets using micro-survey data from Bulgaria. Co-ownership of assets is widespread in many countries due to inheritance. Central and Eastern Europe offers an interesting natural experiment to assess the effects of this type of property rights imperfection because of the asset restitution process in the 1990s. In Bulgaria, where co-ownership is very prominent and land is strongly fragmented, the land reform and inheritance legislation allows identifying the impact of co-ownership by taking advantage of a discontinuity created by a minimum plot size law. We find that land in co-ownership is more likely to be used by less efficient farm organizations or to be left abandoned, and that it is related to significant welfare losses. The paper hence provides evidence of sub-optimal land allocation following a privatization that established formal but imperfect property rights. Journal of Comparative Economics xxx (xx) (2011) xxx-xxx. LICOS Center for Institutions and Economic Performance, Belgium; Department of Earth and Environmental Sciences, University of Leuven (KUL), Belgium; Paris School of Economics, France; INRA, France; European Commission, Belgium; University of Leuven (KUL), Belgium.
\end{abstract}

(C) 2010 Association for Comparative Economic Studies Published by Elsevier Inc. All rights

reserved.

\section{Introduction}

The empirical growth literature often emphasizes property rights as the prime example of how institutions can affect growth (Acemoglu et al., 2001; Acemoglu and Johnson, 2005). The land privatization reforms in Eastern Europe and much of the Former Soviet Union include some of the most radical and swift changes in property rights in recent history. As such they provide a unique opportunity to analyze the impact of property rights. ${ }^{1}$ This paper contributes to the literature on

\footnotetext{
* Corresponding author at: INRA, France.

E-mail addresses: liesbet.vranken@ees.kuleuven.be (L. Vranken), karen.macours@parisschoolofeconomics.eu (K. Macours), Nivelin.noev@cec.eu.int (N. Noev), jo.swinnen@econ.kuleuven.ac.be (J. Swinnen).

1 The evidence from the privatization efforts of other assets in this region suggests that rapid privatization did not always lead to an optimal initial allocation of assets, as local elites often were quick to take advantage of the reforms (Roland, 2002; Glaeser et al., 2001). Yet, privatization did allow the emergence of new companies that generally have outperformed both the transformed and the remaining state-owned companies (Bilsen and Konings, 1998; Konings et al., 2005; Nickell, 1996).
} 
property rights with micro-evidence from Bulgaria and analyzes how, after privatization, remaining imperfections of property rights affect asset allocation. It focuses on post-privatization imperfections of property rights that arose from co-ownership of assets by the children or grandchildren of former owners. This form of co-ownership is widespread in Central and Eastern Europe (Dale and Baldwin, 2000), but has received relatively little attention. The theoretical literature on joint ownership suggests that it might lead to suboptimal investment levels (Hart, 1995) and impede optimal allocation of assets (Holderness, 2003; Deaton, 2006) as transaction costs in decision-making and exercising their rights constrain owners in making optimal decisions. Based on these insights, we hypothesize that co-ownership makes it more likely that assets are allocated to traditional (and often inefficient) users, or are left abandoned. The main objective of this paper is to test this hypothesis and provide an estimate of the magnitude of the impact of co-ownership on plot allocation. We also hypothesize that co-ownership leads to welfare losses, and provide evidence that is consistent with this hypothesis.

Bulgaria offers an interesting natural experiment to analyze these issues, because of the prominence of the co-ownership problem, the strong fragmentation of the land, and because the legislation provides an instrument to separate out chosen versus forced forms of co-ownership. Land privatization in Bulgaria occurred through restitution of physical plots of land to the descendents of families that had owned land prior to the post-WWII collectivization processes. All legal heirs were entitled by descent to part of each plot. To avoid land fragmentation, a law imposed a minimum plot size of 0.3 ha. The law resulted in forced co-ownership of land for many households.

To identify the effect of co-ownership, we exploit the discontinuity caused by this minimum plot size legislation. In particular, we take advantage of the fact that it implies forced co-ownership for plots that would be below the minimum size if they were to be divided among all the legal co-owners. We estimate whether the probability of certain types of plot allocations changes discontinuously at the cut-off plot size, while accounting for the fact that the plot allocation may differ by plot size even if no minimum plot size law exists. Methodologically, this paper hence relates to work that uses regression discontinuity designs to identify causal relationships (e.g. Pitt and Khandker, 1988; Angrist and Lavy, 1999; Van der Klaauw, 2002). Identification further relies on the fact that households' land ownership in Bulgaria had been determined through the land restitution process in the 1990s, and land sales markets had remained very thin. ${ }^{2}$ In addition, households often own multiple plots, allowing the use of household fixed effects in the plot level analysis to control for potential political influence that might have played a role during the restitution process and for other household unobservables. The method used in this paper therefore also relates to Goldstein and Udry (2008) who use variation across plots from the same household to shed light on property rights insecurity in Ghana.

This paper contributes to the literature on property rights by providing micro-evidence of the possible negative effects of imperfect rights. The specific imperfection analyzed in this paper, co-ownership of rights, is important beyond transition countries. Co-ownership of assets is common in many developing countries, and even in the US, mainly after inheritance (Mitchell, 2001; Shoemaker, 2003). By analyzing the effect of legislation that de facto restricts property rights, this paper also relates to research indicating that gains from formal property rights might be limited in the presence of other market imperfections (Carter and Olinto, 2003; Boucher et al., 2005) or weak enforcement institutions (Conning and Robinson, 2007; Macours et al., 2010). ${ }^{3}$ Finally, the analysis relates to Blarel et al. (1992) and Mearns (1999) who analyze policy interventions and legislation targeted at preventing land fragmentation in other settings.

The paper is organized as follows. Section 2 explains the property rights reforms and legislation in Bulgaria, Section 3 discusses the empirical strategy and Section 4 introduces the dataset. In Section 5, we first analyze the impact of forced co-ownership on land allocation. We show that land in forced co-ownership is much more likely to be in a default allocation, i.e. to be used by large-scale cooperatives or to be left abandoned, while it is less likely to be used by individual household farms or de novo agricultural companies. The effect of forced co-ownership is robust to several alternative model specifications, including models considering binary and multi-dimensional allocation choices, and flexible forms to allow for non-linearities in the relationship between plot size and land allocation. Section 6 analyzes the effect of all types of co-ownership on land allocation, using forced co-ownership and the law-related discontinuity in an instrumental variable estimation. After establishing the effects of co-ownership on land allocation, we focus on the efficiency implications of the findings, and show evidence suggesting that co-ownership is related to significant welfare losses. Section 7 concludes.

\section{Background on the land restitution and minimum plot size legislation in Bulgaria}

In Bulgaria, as in many other Eastern European countries, most agricultural land belonging to individual households was forced into agricultural collectives after the Second World War. From the late 1940s through the 1980s, the large majority of all agricultural land was used by collective and state farms, while private household plots only accounted for $13 \%$ of arable land (Table 1). All this changed dramatically in the 1990s. Former communist cooperatives and state farms were liquidated and their assets were transferred to a variety of new farm organizations, including limited liability companies, share holding companies, joint stock companies and new agricultural cooperatives. By 1999, the share of arable land used by restructured

\footnotetext{
${ }^{2}$ In the main empirical estimations, we exclude the few plots that households obtained through other means than restitution, to assure that our identification is not affected by ex-post adjustments. The reasons for the lack of activity on the land sales market are further discussed in Section 2.

3 More generally, it relates to the micro-economic literature on the impact of property rights (Besley, 1995; Field, 2005, 2007; Galiani and Schargrodsky, 2007; Jacoby et al., 2002; Lanjouw and Levy, 2002).
} 
Table 1

Pre-reform agricultural structures in Bulgaria, 1985. Source: NSI, 1994.

\begin{tabular}{lll}
\hline & Share of arable land (\%) & Average size (ha) \\
\hline Agro-industrial complexes comprising of & 80.7 & 12,600 \\
Collective farms & 58.3 & 4000 \\
State farms & 8.8 & 2100 \\
Brigades & 13.6 & n.a. \\
Other agricultural organizations & 6.2 & 1215 \\
Private plots & 13.1 & 0.38 \\
Total & 100 & \\
\hline
\end{tabular}

Table 2

Post-reform agricultural structures in Bulgaria, 1995-1999. Source: NSI, 1997 and 2001.

\begin{tabular}{|c|c|c|c|c|}
\hline & \multicolumn{2}{|l|}{1995} & \multicolumn{2}{|l|}{1999} \\
\hline & Share of arable land (\%) & Average size (ha) & Share of arable land (\%) & Average size (ha) \\
\hline State farms & 6.5 & 310.9 & 1.6 & 241.2 \\
\hline Municipal farms & - & - & 2.0 & n.a. \\
\hline Cooperatives & 40.8 & 815.3 & 36.8 & 482.5 \\
\hline Household farms & 52.5 & 1.4 & 56.0 & 2.6 \\
\hline Farming companies & 0.7 & 283.5 & 3.6 & 378.6 \\
\hline Total & 100.0 & & 100.0 & \\
\hline
\end{tabular}

cooperatives had fallen to $37 \%$ of the agricultural land, while household farms cultivated more than half of the arable land (Table 2). ${ }^{4}$

The effective property rights on the land were restituted to the former landowners, based on the land records of 1946. Given that many original owners were no longer alive, land was transferred to their heirs. According to the Bulgarian Inheritance Law, every heir gets an equal share of the property when the owner dies. ${ }^{5}$ If during the land reform process $X$ parcels had to be divided among $Y$ owners, each owner received $1 / Y$ share of each of these $X$ parcels.

By the end of the 1990 s, more than $80 \%$ of agricultural land titles had been restituted to individuals. The land restitution process resulted in a strong fragmentation of land ownership. The survey data used in this paper were collected 3 years after the restitution was completed (in 2003) and show that in several regions of the country, households owned, on average, more than five plots, with an average plot size of only 0.7 ha (Fig. 1). Moreover, after restitution, a large share of the parcels was co-owned by more than one owner (Fig. 2 and Tables 3a and 3b). Land co-ownership resulted from a combination of factors, including: (a) the method of land restitution; (b) the current inheritance law; (c) the fragmented 1946 ownership structure; (d) the absence of a land market during communism; and (e) difficulties in identifying and locating all the entitled heirs during the restitution process and in reaching an agreement on the division among all of them.

While similar inheritance laws exist in several Western-European countries, co-ownership is less widely observed there because land gets divided among heirs immediately after inheritance and parcels generally do not stay fragmented but are often consolidated through land swaps or rental and sales after the division. Given the absence of any type of land market during Central Planning, such adjustments had not occurred in Bulgaria and the privatization process in the 1990s suddenly "revealed" the massive co-ownership situation. The evidence in this paper sheds light on the impediments that prevented subsequent re-allocation among households through the rental markets. As for the land sales market, frequency of transactions was very low. A World Bank survey in 2004 found that only 3.5\% of all rural households sold land and only $1 \%$ bought land since the start of transition. Similarly, the survey data used in this paper, collected in 2003, show that less than $3 \%$ of households bought land and less than $1 \%$ of the plots were obtained through the sales market. ${ }^{6}$

Co-ownership situations also exists in many other transition countries. In Bulgaria, it is further enhanced by legislation that sets a legal minimum size for a land parcel. To prevent excessive fragmentation of land, by law a plot cannot get a separate ownership title if it is smaller than 0.3 ha. ${ }^{7}$ Vineyards and pastures need to have a minimum size of respectively 0.1 ha

\footnotetext{
4 By 1999, less than $4 \%$ of the arable land was used by state or municipal farms. These farms use state-owned land for their cultivation instead of privately owned land and therefore do not enter the analysis in this paper.

5 Legal heirs are identified based on administrative records, and heirs cannot be excluded by will.

${ }^{6}$ While it might seem surprising that households that have plots in forced co-ownership do not decide to sell their shares to one of the co-owners, note that such a sale would imply the same type of coordination problems among co-owners as a rental transaction. Moreover, the Bulgarian land market at time of the survey (2003) was characterized by a lack of simple, inexpensive, quick and secure legal procedures for transferring land, insufficient documentation of ownership in land registries, slow resolution of legal disputes, and lack of access to credit. Finally, it is not unlikely that new owners were reluctant to sell their land only shortly after receiving it through restitution, at a moment when there was still a lot of economic uncertainty in rural Bulgaria, and given anticipation of land price increases with EU accession (Grover, 2006; Kopeva et al., 2002, 2010; Swinnen et al., 2006).

7 This legislation was part of the Law for Agricultural Land Ownership and Use (LALOU) and the Regulation for Application of the Law for Agricultural Land Ownership and Use (RALALOU), both introduced in 1991. These laws have been changed many times since then (more than 30 times for the LALOU), but the rules regarding the minimum plot size were not affected by these changes.
} 


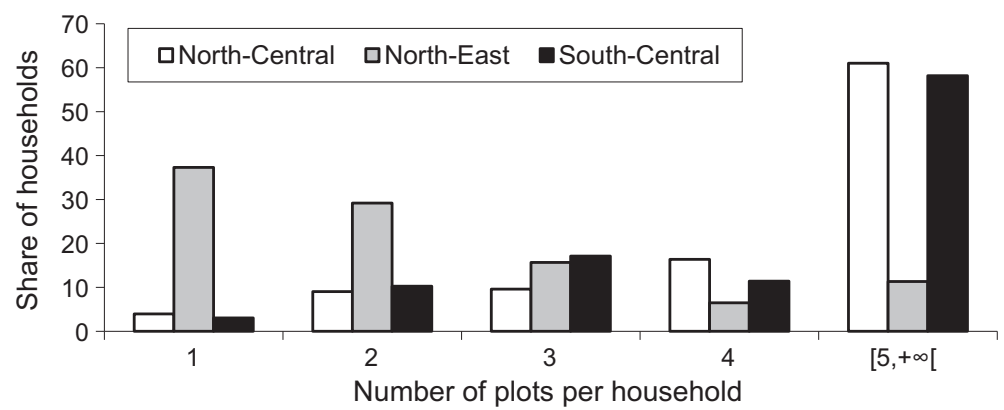

Fig. 1. Number of plots owned per household in 2003 - regional variations.

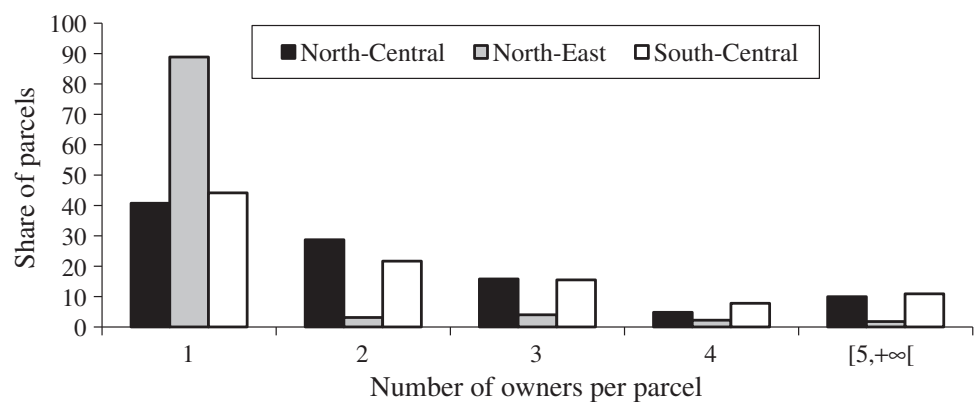

Fig. 2. Number of owners per parcel in 2003 - regional variations.

Table 3a

Descriptive statistics: plot-level variables.

\begin{tabular}{|c|c|c|c|c|c|}
\hline \multirow[t]{2}{*}{$\mathrm{Nr}$ of observations } & \multicolumn{2}{|c|}{$\begin{array}{l}\text { Non co-owned plots } \\
1800\end{array}$} & \multicolumn{2}{|c|}{$\begin{array}{l}\text { Co-owned plots } \\
1775\end{array}$} & \multirow[t]{2}{*}{ Significance difference } \\
\hline & Mean & SD & Mean & SD & \\
\hline \multicolumn{6}{|l|}{ Plot-level data on co-ownership } \\
\hline Share of total sample & 50 & & 50 & & \\
\hline \% Non-divisible by law & & & 79 & & \\
\hline Number of co-owners & - & - & 3.4 & 2 & \\
\hline From the same village & - & - & 1.9 & 2.2 & \\
\hline Not from the same village & - & - & 1.5 & 1.1 & \\
\hline Number of forced co-owners & - & - & 3.1 & 1.8 & \\
\hline From the same village & - & - & 1.8 & 1.1 & \\
\hline Not from the same village & - & - & 1.3 & 1.8 & \\
\hline \multicolumn{6}{|l|}{ Other plot-level variables } \\
\hline Plot size & 0.8 & 1.3 & 0.6 & 2.6 & ** \\
\hline Quality (1-10) & 4.8 & 2 & 5.3 & 2 & *** \\
\hline Distance & 3 & 12 & 3.1 & 8.9 & \\
\hline \multicolumn{6}{|l|}{ Plot allocation } \\
\hline \% Used by the owner & 26 & & 15 & & *** \\
\hline \% Rented out to an other household & 5 & & 2 & & $* * *$ \\
\hline$\%$ Rented out to a cooperative & 30 & & 49 & & $* * *$ \\
\hline \% Rented out to a company & 19 & & 13 & & *** \\
\hline$\%$ Abandoned & 21 & & 22 & & \\
\hline \% Plots over which the owner declares to have effective decision power & 67 & & 32 & & *** \\
\hline
\end{tabular}

*** $p<0.05$.

*** $p<0.01$.

and 0.2 ha. A parcel cannot be divided among heirs if the size of the newly created plots would fall below these levels, a situation which we refer to as "forced" co-ownership.

The officially stated reason for the minimum plot size legislation is to prevent inefficient land use by avoiding excessive land ownership fragmentation. However, because of the law, all co-owners have imperfect property rights, which could result in sub-optimal land allocation, use, and exchange. Before being able to sell or rent out a co-owned plot, all co-owners 
Table 3b

Descriptive statistics: household-level variables.

\begin{tabular}{lll}
\hline & Mean & SD \\
\hline Land ownership and use & & 0.9 \\
Area in co-ownership & 1.9 & 2.5 \\
Area owned solely by one household & 2.4 & 2.4 \\
Total area owned per household & 5.6 & 5.4 \\
Number of plots owned per household & 0.4 & 1.2 \\
Area in owner-cultivation & 61.6 & 3.8 \\
\% Households that cultivated land & 1 & 2.1 \\
Area cultivated by the household & 1.5 & 2.8 \\
Number of plots cultivated per household & 2.8 & 0.8 \\
\% Households that bought land & 2.1 & 12 \\
For those who bought land: Area bought (ha) & 1.5 & 3.1 \\
For those who bought land: \# plots bought & & \\
Other household characteristics & 64.8 & \\
Age household head & 8.9 & 9 \\
Years of education household head & 9 & \\
\% Households that immigrated & 49 & \\
Of which: \% land cultivating & 4 & \\
\% Households that emigrated & 44.5 & 9 \\
\% Of households with some land & 48.6 & \\
Used by the owner & 28.8 & \\
Rented out to an other household & 43.7 & \\
Rented out to a cooperative & & \\
Rented out to a company & & \\
Abandoned & & \\
\hline
\end{tabular}

need to be located and agreed with, which can substantially increase the costs of land re-allocation. More co-owners can also result in larger collective action problems regarding any plot-related tasks or decisions. This then might constrain efficient land use. This paper hypothesizes in particular that co-ownership will make it more likely that the "default option" will prevail. In the context of post-restitution Bulgaria, the default option is either to leave land with the traditional users of the land, which are the former collective farms that are now mostly organized as cooperative farms, or, not using the land at all. If coownership significantly increases the costs involved in (re-) allocating land, we should expect co-owned land plots to be left more abandoned and to be used more by cooperatives, ceteris paribus.

Anecdotal evidence from field interviews suggests that this is often the outcome. To illustrate this, consider two cases. The first case is a household that received 32 ha of land through the restitution process, located in two plots of equal size. The first plot of 16 ha is co-owned by three absentee relatives. The second plot is co-owned by another 25 people, of which 24 have migrated and are now living in Turkey and only one is living in the same village. The first plot is legally rented out to a farming enterprise based on a contract with the three co-owners. The second one falls into a field cultivated by a cooperative from the neighboring city and is cultivated by the cooperative without any contract or written permission given from any of the co-owners. The absence of the co-owners prevents not only the division of the land, but also its withdrawal from the cooperative as the management of the latter refuses to leave the plot, gaining from the unresolved co-ownership issue.

In the second case, in another of the surveyed villages, two companies wanted to rent two plots of, respectively, 6 ha and 7 ha for a period of 15 years while simultaneously investing in a processing facility in the village. It took the two companies 8 months using the efforts of three people - including the mayor of the village - to locate all the co-owners. Costs related to locating co-owners (approximately 90), obtaining their agreement, and registration of the rental contract in the notary, the court and the land commission, had to be covered by the companies.

These examples suggest that co-ownership whether it is because of legal limits (case 2) or because of other constraints (case 1) can be a serious problem, with negative implications for efficiency and welfare. A household's return to its land asset is expected to be lower when the land is in co-ownership because the probability of land being allocated to a low-return default allocation increases when a plot cannot be divided among co-owners and/or decision-making is difficult. The examples also suggest that efficient allocation might be more difficult the larger the number of co-owners. In the rest of this paper we will econometrically assess and quantify how co-ownership affects the allocation of land and households' welfare.

\section{Empirical model and identification}

We hypothesize that co-ownership leads to decision-making problems, which increases the costs of both using the land and changing the land allocation. We therefore analyze whether the allocation of, and the returns to, land differ depending on whether plots are in co-ownership. The plot size legislation allows addressing the concern that co-ownership of land could be endogenous. Certain types of households might choose to keep their land in co-ownership, while others might choose to split it up, and as such there could be an omitted variable bias problem. In particular, the choice on whether to 
keep the land in co-ownership or split it up, is likely to be related to a number of household and plot characteristics, that themselves might also be related to land allocation. ${ }^{8}$ There is however a large share of all co-owned plots that is in forced co-ownership due to the minimum plot size legislation. Hence while incentives to remove land from co-ownership might be related to many household or plot characteristics (such as land quality), we focus on forced co-ownership, for which the owners do not have the choice to remove it from co-ownership). More specifically, the discontinuity that exists around the minimum plot size of 0.3 ha creates the natural experiment this paper exploits to identify the local average treatment effect. Focussing on whether there is a discontinuous change in asset allocation at the 0.3 ha benchmark, allows then to separate the effect of coownership from any confounding factors such as land quality or location.

\subsection{Reduced form: effect of forced co-ownership on plot allocation}

We first analyze whether a plot in forced co-ownership is more likely to stay in one of the default options. Let $y$ be the outcome variable indicating whether household $h$ leaves plot $i$ abandoned or rented out to a cooperative. ${ }^{9}$ The binary choice model has the following form:

$$
\operatorname{Prob}\left(y_{i h}=1\right)=F\left(z_{i h} \beta\right)
$$

with $F$ being the standard logistic distribution, or the uniform distribution and

$$
z_{i h} \beta=\beta_{0}+\beta_{1} d_{i}+\beta_{2} x_{i}+\beta_{3} x_{i}^{2}+\beta_{4} x_{i}^{3}+\beta_{5} q_{i}+\beta_{6} l_{i}+\eta_{h}+\varepsilon_{i h}
$$

where $d_{i}$ is a plot-specific variable capturing forced co-ownership. In particular, we define two variables to measure forced co-ownership. In a first specification, $d_{i}$ measures whether a plot is non-divisible by law, and equals 1 if the plot cannot be legally divided and 0 if a plot is not in co-ownership or, if co-owned, could legally be divided among co-owners. Given that the decision-making problems are likely to increase with the number of co-owners, in a second specification, $d_{i}$ measures the number of forced co-owners, equalling the number of co-owners if the plot cannot be legally divided and 0 if a plot is not in co-ownership or, if co-owned, could legally be divided among co-owners.

As for the other definitions, $x_{i}$ is the plot size, $q_{i}$ is a variable measuring land quality, based on the Bulgarian land classification system that assigns to each plot a score between 1 and 10 , with 1 being the highest quality and 10 the lowest; and $l_{i}$ a variable measuring the distance in kilometers of the plot to the house of the owner. $\beta_{1}$ is the main parameter of interest capturing the effect of forced co-ownership and $\beta_{2}, \ldots, \beta_{6}$ are the parameters of the plot-level control variables. $\eta_{h}$ captures household-level unobservables that will be accounted for through household-level fixed effects. All regressions account for sampling weights and only include households with variation in plot allocation, as others cancel out with the fixed effect.

The definitions of forced co-ownership, and hence the identification in this paper, depend on the plot's size and on the number of legal heirs at the time of restitution. Plot size is determined through the restitution process and reflects the historical situation after the Second World War. And for a given plot size, whether a plot could be divided depends on the number of legal heirs to the plot at the time of restitution. Variation in the number of legal heirs at the time of restitution comes from differences in fertility, and mostly from differences in life cycles and variations in age-of-death of both the original 1946 owners and their children. As a result, among plots of the same size, property rights were allocated to many households for some plots, while ownership for other plots was given to few households. In the later case, the minimum plot size legislation is less likely to be binding.

Land was not always restituted in historical boundaries but instead household sometimes received plots of the same size as their 1946 plots but in different locations. This could raise a concern for the identification as households with local political power or influence might have received plots that were located next to each other - and therefore could be consolidated, while people without influence on the restitution decision might have been more likely to receive fragmented parcels. ${ }^{10}$ It is hence theoretically possible that certain households managed to lobby for larger consolidated plots in response to the minimum plot size legislation, and these same households also lobbied for plots of higher quality or better location. Finding a relationship between forced co-ownership and plot allocation, might then merely reflect this correlation. We address this potential concern by including household fixed effects in the plot-level estimation, explicitly accounting for any potential household influence during the restitution process. While factors determining the number of legal heirs such as fertility and age-of-death might

\footnotetext{
8 The direction of the potential bias is not necessarily clear. It could be, for instance, that households with high opportunity costs of time (possibly outside of agriculture) or lower quality land would be less likely to go through the process of locating other co-owners in order to split-up the land, and would also be more likely to leave the land in the cooperative. This would lead to an upward bias of the estimate of co-ownership on the likelihood of leaving land in a cooperative in an OLS estimation. Alternatively, it is possible that households who want to cultivate land themselves might also be households that are more likely to have co-owned land because they are less successful in locating co-owners (for instance, because of lower levels of education, or difficult access to transport), which would lead to a downward bias in an OLS estimate. It is also possible that higher returns on plots that are cultivated by individual households are the reason why the co-owners of the plot (who might also be co-investors in the land) would not want to split the land, which would also lead to a downward bias.

${ }^{9}$ In the main specification in this paper, land abandonment and renting to a cooperative are grouped together as the default option. The underlying assumption is specifically tested through estimating a more flexible multinomial logit model (see Table 6).

${ }^{10}$ To illustrate this, consider a group of two heirs who through restitution received two plots that were disconnected, each of 0.4 ha. They would be unable to divide each of those plots. However, if they received two plots, each of 0.4 ha, that were connected to each other, they effectively had the rights to a plot of 0.8 ha, which they then could split-up without violating the minimum plot size law.
} 
be correlated with socio-economic status and therefore also possibly with the plot characteristics, these are also controlled for by the household fixed-effects. The identification thus relies on the plot size discontinuity, and on variation in the number of legal heirs of different plots of the same household. The later variation is due to the fact that both spouses might have been restituted land that belonged to their respective families in $1946 .^{11}$

The analysis further controls for plot quality and location. While good measures of land quality are often lacking in empirical work on land markets, this paper takes advantage of a detailed land quality classification system in Bulgaria, which classified each plot in 1980s on a 10-point scale. The scale is based on a scientific evaluation of very detailed soil and climate information (texture of the soil cover, the presence of moisture during the vegetation period, the availability of warmth in the area especially in the vegetation period, extreme manifestation of certain factors in climate change, the altitude above sea level, the topography, etc.). A quantification of these different indicators, together with an evaluation of the different types of crop the land can sustain, and it's irrigation potential, results in a score between 1 and 100 . This is then converted into the 10-point scale that we have access to for this paper. Importantly the scores for each plot were determined in 1980 , i.e. before any restitution could have been anticipated, and is hence not a function of plot use or present allocation (Ministry of Agriculture and Food of the Republic of Bulgaria, 2009).

By adding a smooth function of plot size, we guarantee that the identification comes from the discontinuity, and not from any allocation decisions that merely reflect plot size. Alternatively, we add a cubic function of plot size divided by the number of co-owners. While the later specification has the advantage of using the variable used to define the threshold, it has the disadvantage that the number of co-owners is a choice variable for those plots that are above the threshold. Moreover, we would expect plot size itself to affect allocation directly. We hence show results with both specifications. We also show results using only a subsample of plots in a narrow band around the discontinuity point, to further eliminate any direct plot size effects.

\subsection{Partial linear estimator}

To illustrate the empirical relevance of the discontinuity, we also estimate a partially linear estimator, following Porter (1999). ${ }^{12}$ Let $y$ be the outcome variable indicating whether the plot is abandoned or rented out to a cooperative, $x$ gives the plot size divided by the number of co-owners, $m()$ is continuous in $x$, and $d$ is the dummy capturing whether the plot is undivisible by law. ${ }^{13}$

$$
y=m(x)+d \alpha+\varepsilon \quad \text { where } E(\varepsilon \mid x, d)=0
$$

By subtracting the conditional expectation with respect to $x$ from both sides, we get

$$
y-E(y \mid x)=\alpha(d-E(d \mid x))+\varepsilon
$$

We use locally weighted regressions to estimate the conditional expectations of $y$ and $d$ and calculate $y-E(y \mid x)$ and $d-E(d \mid x)$. We then apply least squares to these differences to obtain an estimate of $a$, i.e., the magnitude of the jump in the relationship between land allocation and plot size per owner at the cut-off criteria and bootstrap to obtain the standard errors. $^{14}$

\subsection{IV estimates: effect of co-ownership on plot allocation}

After establishing the effect of forced co-ownership, we proceed with identifying the effect of co-ownership more broadly, taking advantage of the frequency of forced co-ownership in the sample. The exogenous variation in forced co-ownership results from the minimum plot size legislation is used as an instrument for co-ownership. Consider a model specified as in (1) with $\mathrm{F}$ being the uniform distribution and

$$
z_{\text {ih }} \beta=\beta_{0}+\beta_{1} \text { coown }_{i}+\beta_{1} x_{i}+\beta_{2} x_{i}^{2}+\beta_{3} x_{i}^{3}+\beta_{4} q_{i}+\beta_{5} l_{i}+\eta_{h}+\varepsilon_{i h}
$$

with coown $n_{i}$ capturing the number of co-owners. coown $i$ is instrumented with $d_{i}$, using the binary indicator of whether the plot is non-divisible by law, or alternatively the number of forced co-owners.

\section{Data}

The analysis is based on household and plot-level data collected in 2003 in 18 communities, randomly sampled in three Bulgarian regions. The regions were selected to reflect important variations in the rural economy, agricultural structure, and geographical conditions. Detailed household and plot level information was gathered from 700 households through

\footnotetext{
11 To isolate the identification through the plot size from the identification from the number of legal heirs, one would want to compare plots just above and below the cut-off with the same number of legal heirs at the time of restitution. However, lack of information on the number of legal heirs for those plots that have been divided prevents using such an approach

12 This estimate is mainly meant to illustrate the discontinuity graphically, as it does not allow controlling for confounding factors discussed above.

13 Given that all variables in this partial linear model are plot-level variables, the subscripts $i$ are suppressed.

$14 \alpha$ is the equivalent of $\beta_{1}$ in Eq. (2).
} 


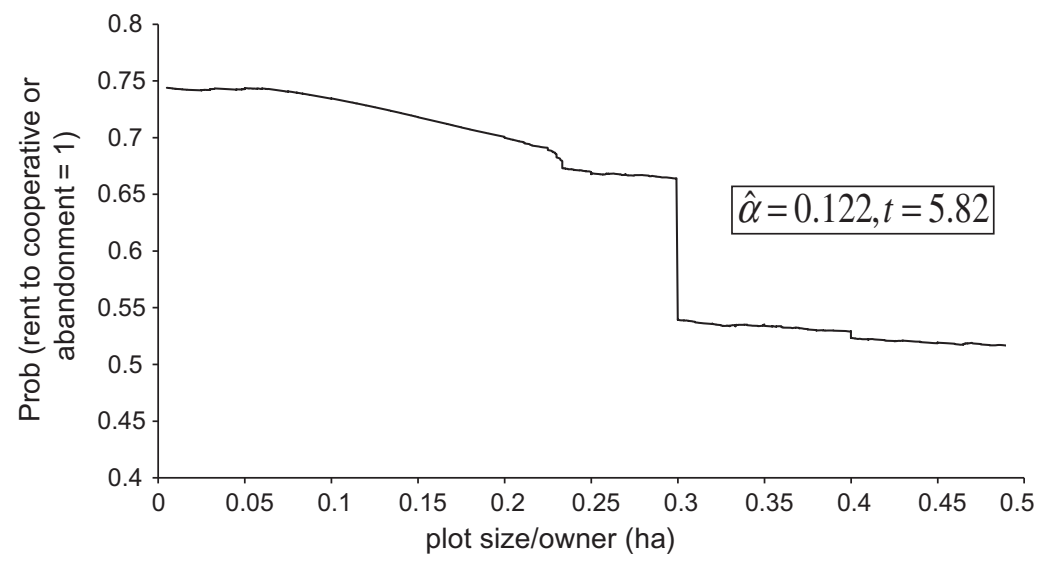

Fig. 3. Probability that a plot is rented out to a cooperative or left abandoned by plot size.

interviews with key informants and household members. The households were selected using a stratified random sampling frame, with stratification based on whether they rented land from other households. ${ }^{15}$

A possible drawback of the data is that the plot sizes and ownership are only observed in 2003 and may not reflect the situation at the time of restitution because households might have tried to adjust plot sizes in response to the minimum plot size legislation through market mechanisms. But, as discussed, land purchases are very rare in rural Bulgaria. And of the plots that were obtained through sales, only two are in co-ownership (implying they might have been bought jointly) and these are large plots for which the law is not binding. On the other hand, $88 \%$ of all plots in the sample was obtained directly through the restitution process. For restituted plots in co-ownership, the number of co-owners is the number of legal heirs at the time the plot was restituted, which is predetermined given the inheritance legislation discussed above. About $9 \%$ of plots is reported to be obtained through inheritance, possibly after restitution. For these plots, we cannot be sure that the number of co-owners in 2003 is the same as the number of legal heirs at the time of restitution. ${ }^{16}$ For the main results of the paper, we will therefore only include plots that were directly obtained through restitution.

Table 3a illustrates the co-ownership issue. 50\% of all parcels owned by the sampled households are in co-ownership. One-fifth of the parcels are owned by two households, another $14 \%$ have three co-owners, and around $16 \%$ of the parcels are owned by at least four co-owners (Fig. 2). More than $40 \%$ of the parcels owned by rural households (and $79 \%$ of all co-owned plots) are in forced co-ownership and cannot be divided among the owners by law. Interestingly, owners declare to have effective decision power over $67 \%$ of non co-owned plots, but only for $32 \%$ of the co-owned plots. The descriptive statistics also show that land fragmentation is quite strong. Households own an average of 5.6 plots, while the average plot size is about 0.7 ha (Tables $3 a$ and $3 b$ ).

The main form of land exchange is through the rental market. Seventy-eight percent of all land owning households in the survey rent out land and $20 \%$ of the land cultivating households are renting land from others. Around $40 \%$ of the parcels that are owned by the surveyed households are rented out to a cooperative and $16 \%$ is rented out to a farming company. Twenty percent of the parcels are cultivated by the owners. The plot allocation is significantly different when comparing co-owned plots versus non co-owned plots (Table 3a). At the household level, 49\% of all land owning households are renting out some land to a cooperative and $29 \%$ to a farming company (Table 3b). Further, $9 \%$ of the landowning households are renting out land to another household, but only 3\% of the parcels owned by rural households are exchanged with other households. Finally, land abandonment is remarkably widespread. ${ }^{17}$ Twenty-two percent of plots is left idle, and more than $40 \%$ of all land owning households leave some land idle.

The binary dependent variable indicating default plot allocation equals 1 if the plot is left abandoned, or rented out to a cooperative, and 0 for the other allocations. To provide empirical support for the use of this definition, we also estimate a more flexible multinomial logit model allowing for the broader choice between all five possible allocations, i.e. ownercultivation, renting out to another farming household, renting out to a company, renting out to a cooperative, and leaving

\footnotetext{
15 This stratification was followed because the data was originally collected to shed light on households' participation on both sides of the rental markets. As households' decisions to rent land from others and decisions about the allocation of their own land are clearly related, the sampling frame is accounted for in the empirical analysis through weights in the regressions. Manski and Lerman (1977) show that such weights are necessary to achieve consistency in such choice-based samples. That said, the results are robust to non-inclusion of the sampling weights.

16 The remaining $2 \%$ of plots was acquired through a variety of mechanisms, such as donations, compensation for past services, and land claims on unused land. There is no evidence of co-owners exchanging different plots of land among themselves after restitution. While it is possible that this has occurred informally (e.g. two siblings who both own half of two plots, might each work one of them and agree not to pay each other rent), the information in the data reflects the formal number of legal heirs after restitution for each co-owned plot. Anecdotal evidence also suggests that informal arrangements to circumvent the law were rare.

17 Plots are defined as abandoned if they are not under any sort of cultivation and are also not used for pasture, fodder, or forest.
} 


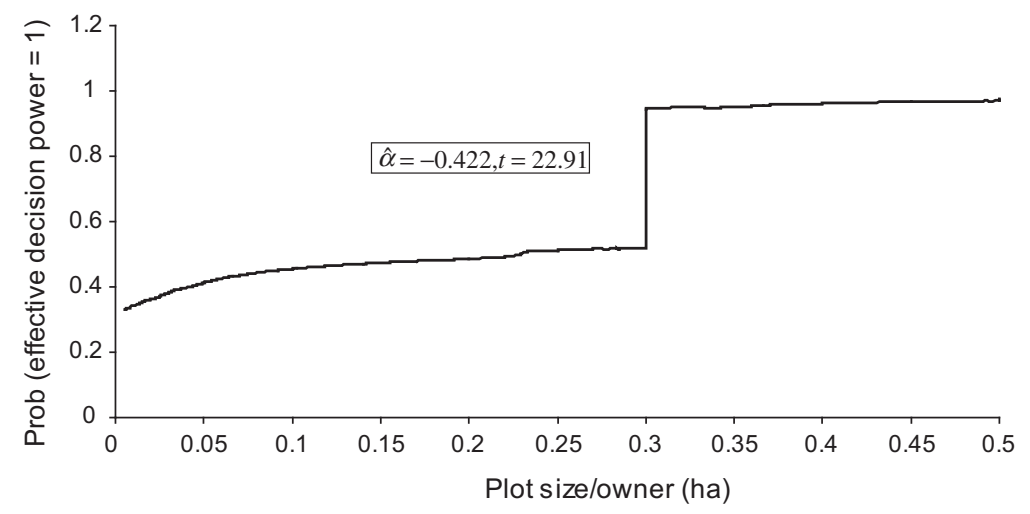

Fig. 4. Probability that the owner has effective decision power on the plot by plot size.

abandoned. Finally, in Section 6 we will consider the relationship between co-ownership and welfare. To measure welfare, we follow Finan et al.'s (2005) analysis of the relationship between land ownership and welfare, and constructed a welfare index based on a principal component analysis accounting for key household assets. ${ }^{18}$

\section{Results: plot allocation choice and forced co-ownership}

First, Fig. 3 shows results of the locally linear estimator (Eq. (3)), confirming that there is a large and significant discontinuity in the relationship at the minimum plot size of 0.3 ha. People with plots in forced co-ownership also report to have significantly lower decision-making power on those plots. In a similar regression using the answer to a question that asked whether people perceived to have effective decision-making power on a plot, we find an even larger and very significant discontinuity (Fig. 4). Fig. 3 further illustrates that the relationship between plot size per owner and the dependent variables does not show any substantial non-linearities at points other than the cut-off point, suggesting that once a smooth function of plot size per owner is accounted for, there are unlikely to be substantial biases in the estimation of Eqs. (1) and (2) due to misspecification of the functional form.

The results corresponding to Eqs. (1) and (2) are shown in Table 4. Columns 1 and 4 show results for a subsample of plots in a narrow band around the discontinuity (plots between 0.15 and 0.45 ha), columns 2 and 5 show results for a somewhat wider band around the discontinuity (plots between 0.1 and 0.5 ha) and columns 3 and 6 show results for the full sample of restituted plots. Both the logit and the linear probability results show that plots in forced co-ownership are much more likely to be left in the default option, even after controlling for household unobservables. The point estimates are significant in all specifications and are the largest when we only consider plots close to the threshold, for which the estimate based on the discontinuity is most relevant. Not surprisingly, the plot size variables are not significant for the estimations on the subsamples, but are significant on the full sample. When substituting the cubic of plot size with the cubic of plot size per co-owner (bottom panel of Table 4) we obtain very similar results, and the point estimates on forced co-ownership are robust to this change in specification. Turning to the second indicator of forced co-ownership, results in Table 5 show that the higher the number of forced co-owners, the more likely the plot is abandoned, or is left in the cooperative.

In both Tables 4 and 5, the plot control variables are related to plot allocation as expected. More remote plots, and plots with lower quality are more likely to be in one of the default allocation. The plot-level variables explain a substantial part of the variation in the data, as the $R$-squared of the model without plot characteristics is $8-11 \%$ point lower than in the model that controls for plot size, quality and location. Table 5 further shows that the estimated effect of the number of forced coowners is robust to the exclusion of the plot characteristics. Hence, when household unobservables are controlled for, the remaining correlation between plot characteristics and the number of forced co-owners appears to be limited. The last specification in Table 5 shows that results for the sample of plots that includes those that were obtained through inheritance or sale, are broadly consistent, though the point estimates are somewhat smaller than on the sample of plots directly obtained through restitution. ${ }^{19}$

Overall, Tables 4 and 5 shows a strong and robust relationship between forced co-ownership and plot allocation, controlling for a flexible function of plot size. This is important given that the forced co-ownership is tied to plot size. Finding the effect of forced co-ownership after controlling for general plot size effects, suggests that decision-making on plots affected by the minimum-size law is different than decision-making on other plots. Specifically, focusing on the results of plots most

\footnotetext{
18 The principal component analysis is based on ownership of a house, car, color TV, black and white TV, video, personal computer, telephone, and cell phone. The first component is used as the welfare index. It captures more than $33 \%$ of the total variance and has an Eigen value that is twice as high than the second principal component. The index is standardized to have mean zero and has a standard deviation of 1.63.

19 The results are further robust to exclusion of pastures and vineyards (11\% of plots in the sample), which have a lower minimum plot size.
} 
Table 4

Impact of forced co-ownership on the probability of default plot allocation with household-level fixed effects.

\begin{tabular}{|c|c|c|c|c|c|c|}
\hline & \multicolumn{3}{|c|}{ Logit (marginal effects) } & \multicolumn{3}{|l|}{ OLS } \\
\hline & (1) default & (2) default & (3) default & (4) default & (5) default & (6) default \\
\hline \multicolumn{7}{|l|}{ Controlling for cubic of plot size } \\
\hline \multirow[t]{2}{*}{ Non-divisible by law } & $0.402^{* * *}$ & $0.442^{* * *}$ & $0.286^{* *}$ & $0.282^{* *}$ & $0.288^{* * *}$ & $0.190^{* *}$ \\
\hline & $(0.105)$ & $(0.075)$ & $(0.110)$ & $(0.091)$ & $(0.086)$ & $(0.082)$ \\
\hline \multirow[t]{2}{*}{ Plot size (ha) } & 0.261 & 0.109 & $0.0620^{* * * *}$ & 0.062 & 0.076 & $0.028^{* * * *}$ \\
\hline & $(0.292)$ & $(0.098)$ & $(0.018)$ & $(0.111)$ & $(0.056)$ & $(0.007)$ \\
\hline \multirow[t]{2}{*}{$(\text { Plot size })^{\wedge} 2$} & -0.030 & -0.003 & $-0.001^{* * *}$ & -0.001 & -0.005 & $-0.000^{* * *}$ \\
\hline & $(0.0318)$ & $(0.021)$ & $(0.000)$ & $(0.015)$ & $(0.011)$ & $(0.000)$ \\
\hline \multirow[t]{2}{*}{$(\text { Plot size })^{\wedge} 3$} & 0.001 & 0.000 & $0.000^{* * * *}$ & 0.000 & 0.000 & $0.000^{* * * *}$ \\
\hline & $(0.001)$ & $(0.001)$ & $(0.000)$ & $(0.001)$ & $(0.000)$ & $(0.000)$ \\
\hline \multirow{4}{*}{$\begin{array}{l}\text { Plot land quality index }(1-10) \\
\text { ( } 1 \text { = best; } 10=\text { worst) } \\
\text { Plat location (km to house) }\end{array}$} & $0.125^{* *}$ & $0.101^{* *}$ & $0.095^{* * * *}$ & $0.072^{* *}$ & $0.059^{*}$ & $0.060^{* * * *}$ \\
\hline & $(0.040)$ & $(0.040)$ & $(0.019)$ & $(0.025)$ & $(0.028)$ & $(0.014)$ \\
\hline & $0.146^{* * *}$ & $0.111^{* * *}$ & $0.0419^{* *}$ & $0.043^{* * *}$ & $0.023^{* * *}$ & $0.010^{* * * *}$ \\
\hline & $(0.029)$ & $(0.029)$ & $(0.016)$ & $(0.006)$ & $(0.010)$ & $(0.003)$ \\
\hline Observations & 332 & 670 & 1903 & 332 & 670 & 1903 \\
\hline$R$-squared & - & - & - & 0.40 & 0.36 & 0.34 \\
\hline \multicolumn{7}{|c|}{ Controlling for cubic of plot size/number of coowners } \\
\hline \multirow[t]{2}{*}{ Non-divisible by law } & $0.479^{* * *}$ & $0.480^{* * *}$ & $0.236^{* *}$ & $0.350^{* *}$ & $0.374^{* *}$ & $0.158^{*}$ \\
\hline & $(0.140)$ & $(0.083)$ & $(0.099)$ & $(0.135)$ & $(0.134)$ & 0.080 \\
\hline \multirow[t]{2}{*}{ Plot size (ha)/\# of co-owners } & -3.778 & -0.376 & $0.056^{* *}$ & -2.361 & -0.299 & $0034^{* * *}$ \\
\hline & $(2.429)$ & $(1.142)$ & $(0.026)$ & $(1.840)$ & $(0.698)$ & $(0.010)$ \\
\hline \multirow[t]{2}{*}{$(\text { Plot size/\# of co-owners })^{\wedge} 2$} & 1.412 & 0.221 & -0.001 & 0.867 & 0.156 & $-0.000^{* *}$ \\
\hline & $(0.932)$ & $(0.439)$ & $(0.001)$ & $(0.694)$ & $(0.266)$ & $(0000)$ \\
\hline \multirow[t]{2}{*}{$($ Plot size/\# of co-owners)^^} & -0.161 & -0.028 & $0.000^{* *}$ & -0.097 & -0.019 & $0.000^{* * *}$ \\
\hline & $(0.111)$ & $(0.049)$ & $(0.000)$ & $(0.082)$ & $(0.029)$ & 0.000 \\
\hline Plot land quality index (1-10) & $0.119^{* * *}$ & $0.103^{* *}$ & $0.0902^{* * * *}$ & $0.070^{* *}$ & $0.059^{*}$ & $0.059^{* * *}$ \\
\hline ( 1 = best; 10 = worst $)$ & $(0.034)$ & $(0.042)$ & $(0.019)$ & $(0.024)$ & $(0.028)$ & $(0.014)$ \\
\hline \multirow{2}{*}{ Plot location (km to house) } & $0.148^{* * *}$ & $0.113^{* * * *}$ & $0.042^{* *}$ & $0.043^{* * *}$ & $0.024^{* *}$ & $0.012^{* * *}$ \\
\hline & $(0.031)$ & $(0.029)$ & $(0.016)$ & $(0.007)$ & $(0.009)$ & $(0.004)$ \\
\hline Plot characteristics & Yes & Yes & Yes & Yes & Yes & Yes \\
\hline Observations & 332 & 670 & 1903 & 332 & 670 & 1903 \\
\hline$R$-squared & - & - & - & 0.393 & 0.361 & 0.332 \\
\hline
\end{tabular}

Note: Sample in columns 1 and 4 restricted to plots around discontinuity point with 0.15 ha < plot size/\# co-owners < 0.45 ha; and in columns 2 and 5 restricted to plots with 0.1 ha $<$ plot size/\# co-owners $<0.5$ ha. All regressions include household fixed effects and only include households with variation in plot allocation, and plots obtained directly through restitution. Robust standard errors in parentheses, corrected for clustering at community level. All regressions account for sampling weights.

* $p<0.1$.

** $p<0.05$.

*** $p<0.01$

closely to the threshold (columns 1 and 4), we find that the forced co-ownership increases the probability of leaving the land in a cooperative or abandoned between $28 \%$ and $40 \%$ points. These magnitudes are larger than in the partial linear estimation, suggesting that not controlling for household fixed effects and control variables, while still identifying an impact in the same direction, leads to an underestimation of the magnitude of the impact of forced co-ownership.

\subsection{Considering all possible plot allocations}

So far, we have considered the binary choice between leaving the land in a default allocation (renting to cooperative or abandonment), versus any other allocation. This was motivated by the fact that these two allocations involve the least decision-making on the part of the owners. A multinomial logit that allows for more flexible choices of land allocation provides further support for this division of possible land allocations. For each plot, the household decides more generally among these five allocations: (1) owner-cultivation; (2) renting out to another farming household; (3) renting out to a cooperative, which is typically a successor organization of a former collective farm; (4) renting out to a company; and (5) abandoning. To analyze the effect of forced co-ownership on the choice between these different allocations, let $Y_{i h}$ be a variable that indicates the allocation choice of plot $i$ of household $h$, and $k=1,2, \ldots, J$ representing the five allocation choices.

$$
\operatorname{Prob}\left(Y_{i h}=k\right)=\frac{e^{z_{i h} \beta_{j}}}{\sum_{k=1}^{J} e^{z_{i h} \beta_{k}}} \quad \text { for } k=1,2, \ldots J
$$

As before, $z_{i h}$ includes the variable capturing the imperfection of the property rights on the plot based on the discontinuity, and variables capturing plot characteristics (a cubic of plot size, plot quality and plot location). The multinomial logit cannot be estimated with household fixed effects for lack of sufficient intra-household variation, i.e. there are only few 
Table 5

Impact of number of forced co-owners on the probability of default plot allocation with household-level fixed effects.

\begin{tabular}{|c|c|c|c|c|c|c|}
\hline & \multicolumn{3}{|c|}{ Logit (marginal effects) } & \multicolumn{3}{|l|}{ OLS } \\
\hline & (1) default & (2) default & (3) default & (4) default & (5) default & (6) default \\
\hline \multicolumn{7}{|l|}{ Controlling for cubic of plot size } \\
\hline Number of forced co-owners & $\begin{array}{l}0.186^{* *} \\
(0.080)\end{array}$ & $\begin{array}{l}0.231^{\text {** }} \\
(0.081)\end{array}$ & $\begin{array}{l}0.132^{* * *} \\
(0.039)\end{array}$ & $\begin{array}{l}0.122^{* *} \\
(0.049)\end{array}$ & $\begin{array}{l}0.125^{* * *} \\
(0.028)\end{array}$ & $\begin{array}{l}0.074^{* * *} \\
(0.012)\end{array}$ \\
\hline Plot size (ha) & $\begin{array}{l}0.353 \\
(0.296)\end{array}$ & $\begin{array}{l}0.172 \\
(0.098)\end{array}$ & $\begin{array}{l}0.059^{* * *} \\
(0.018)\end{array}$ & $\begin{array}{l}0.129 \\
(0.120)\end{array}$ & $\begin{array}{l}0.115^{*} \\
(0.053)\end{array}$ & $\begin{array}{l}0.027^{* * *} \\
-0.007\end{array}$ \\
\hline$(\text { Plot size })^{\wedge} 2$ & $\begin{array}{l}-0.049 \\
(0.032)\end{array}$ & $\begin{array}{r}-0.018 \\
(0.020)\end{array}$ & $\begin{array}{l}-0.001^{* * *} \\
(0.000)\end{array}$ & $\begin{array}{l}-0.015 \\
(0.016)\end{array}$ & $\begin{array}{l}-0.014 \\
(0.010)\end{array}$ & $\begin{array}{l}-0.000^{* * *} \\
(0.000)\end{array}$ \\
\hline$(\text { Plot size })^{\wedge} 3$ & $\begin{array}{l}0.002^{*} \\
(0.001)\end{array}$ & $\begin{array}{l}0.001 \\
(0.001)\end{array}$ & $\begin{array}{l}0.000^{* * * *} \\
(0.000)\end{array}$ & $\begin{array}{l}0.001 \\
(0.001)\end{array}$ & $\begin{array}{l}0.001 \\
(0.000)\end{array}$ & $\begin{array}{l}0.000^{* * * *} \\
(0.000)\end{array}$ \\
\hline Plot land quality index (1-10) & $0.123^{* * *}$ & $0.100^{* *}$ & $0.095^{* * * *}$ & $0.072^{* *}$ & $0.061^{*}$ & $0.060^{* * * *}$ \\
\hline$(1=$ best; $10=$ worst $)$ & $(0.039)$ & $(0.038)$ & $(0.019)$ & $(0.025)$ & $(0.028)$ & $(0.014)$ \\
\hline Plot location (km to house) & $\begin{array}{l}0.147^{* * *} \\
(0.031)\end{array}$ & $\begin{array}{l}0.105^{* * *} \\
(0.028)\end{array}$ & $\begin{array}{l}0.042^{* *} \\
(0.016)\end{array}$ & $\begin{array}{l}0.043^{* * *} \\
(0.006)\end{array}$ & $\begin{array}{l}0.024^{* * *} \\
(0.009)\end{array}$ & $\begin{array}{l}0.011^{* * * *} \\
(0.003)\end{array}$ \\
\hline Observations & 332 & 670 & 1903 & 3312 & 670 & 1903 \\
\hline$R$-squared & - & - & - & 0.39 & 0.36 & 0.36 \\
\hline \multicolumn{7}{|c|}{ Controlling for cubic of plot size/number of coowners } \\
\hline Number of forced co-owners & $\begin{array}{l}0.254^{* * *} \\
(0.112)\end{array}$ & $\begin{array}{l}0.284^{* * * *} \\
(0.087)\end{array}$ & $\begin{array}{l}0.133^{* * *} \\
(0.034)\end{array}$ & $\begin{array}{l}0.162^{* *} \\
(0.053)\end{array}$ & $\begin{array}{l}0.162^{* * * *} \\
(0.042)\end{array}$ & $\begin{array}{l}0.076^{* * * *} \\
(0.011)\end{array}$ \\
\hline Plot characteristics & Yes & Yes & Yes & Yes & Yes & Yes \\
\hline Observations & 332 & 670 & 1903 & 332 & 670 & 1903 \\
\hline$R$-squared & - & - & - & 0.395 & 0.366 & 0.353 \\
\hline \multicolumn{7}{|l|}{ Without plot characteristics } \\
\hline Number of forced co-owners & $\begin{array}{l}0.173^{* * *} \\
(0.083)\end{array}$ & $\begin{array}{l}0.210^{* * * *} \\
(0.067)\end{array}$ & $\begin{array}{l}0.102^{* * * *} \\
(0.031)\end{array}$ & $\begin{array}{l}0.130^{* *} \\
(0.044)\end{array}$ & $\begin{array}{l}0.133^{\text {*** }} \\
(0.027)\end{array}$ & $\begin{array}{l}0.067^{* * * *} \\
(0.012)\end{array}$ \\
\hline Plot characteristics & No & No & No & No & No & No \\
\hline Observations & 332 & 670 & 1903 & 332 & 670 & 1903 \\
\hline$R$-squared & - & - & - & 0.28 & 0.29 & 0.28 \\
\hline \multicolumn{7}{|c|}{ Including plots obtained through sales and inheritance } \\
\hline Number of forced co-owners & $\begin{array}{l}0.133 \\
(0.099)\end{array}$ & $\begin{array}{l}0.120 \\
(0.083)\end{array}$ & $\begin{array}{l}0.115^{* * *} \\
(0.029)\end{array}$ & $\begin{array}{l}0.090 \\
(0.058)\end{array}$ & $\begin{array}{l}0.084^{*} \\
(0.043)\end{array}$ & $\begin{array}{l}0.068^{* * * *} \\
(0.011)\end{array}$ \\
\hline Plot characteristics & Yes & Yes & Yes & Yes & Yes & Yes \\
\hline Observations & 381 & 772 & 2198 & 381 & 772 & 2198 \\
\hline$R$-squared & - & - & - & 0.39 & 0.34 & 0.36 \\
\hline
\end{tabular}

Note: Sample in columns 1 and 4 restricted to plots around discontinuity point with 0.15 ha < plot size/\# co-owners < 0.45 ha; and in columns 2 and 5 restricted to plots with 0.1 ha < plot size/\# co-owners $<0.5$ ha. All regressions include household fixed effects and only include households with variation in plot allocation. The first three specifications include only plots obtained directly through restitution, the fourth specification includes all plots. Plot characteristics included are plot size, plot size ${ }^{\wedge} 2$, plot size^3, plot quality index and plot location (distance to from plot to house). Robust standard errors in parentheses, corrected for clustering at community level. All regressions account for sampling weights.

${ }^{*} p<0.1$

*** $p<0.05$.

*** $p<0.01$.

households with all the different possible allocations for different plots. Instead we include observed exogenous household characteristics, in particular the total amount of land owned by a household, age and education of the household head, the square of this age and education, and regional fixed effects. ${ }^{20}$ We also present a specification without plot-level variables, as some of them might be correlated with household unobservables. To estimate the multinomial logit model, we assume that $\beta_{1}=0$, taking owner-cultivation as base category. The remaining coefficients $\beta_{j}$ for $j=2,3, \ldots, J$ hence measure the change relative to owner-cultivation. Standard errors are corrected for clustering at the community level, and regressions account for sampling weights. ${ }^{21}$

The multinomial logit regression coefficients in Table 6 show the likelihood of the different allocations, relative to ownercultivation. The results show that the higher the number of forced co-owners, the more likely the plot is to be rented out to a cooperative, and the more likely it is to be abandoned. As before, plot characteristics help explain plot allocation but the re-

\footnotetext{
20 Given the concerns about bias related to household unobservables (discussed in Section 3 ) and the empirical evidence of such bias, the binary choice model with the household fixed effects is our preferred specification. The multinomial logit is presented here to support the grouping of the two default choices together. As fixed effects are not included, it can be estimated on the full sample of households, not just for households for whom there exists variation in the plot allocation. As such, it also provides a robustness check regarding possible sample selection concerns that could result because the fixed effects model necessarily excludes households with only one allocation in the binary choice model.

21 Comparable results are obtained when correcting standard errors for clustering at the level of the household, to account for correlation of choices between plots from the same household, and when including community fixed effects.
} 
Plot allocation decision: multinomial logit with owner-cultivation as base.

\begin{tabular}{|c|c|c|c|c|}
\hline & \multicolumn{4}{|c|}{ Controlling for plot characteristics } \\
\hline & Rent to other hh & Rent to cooperative & Rent to company & Abandon \\
\hline $\begin{array}{l}\text { Controlling for plot characteristic } \\
\text { \# forced co-owners }\end{array}$ & $\begin{array}{l}-0.116 \\
(0.22)\end{array}$ & $\begin{array}{l}0.421^{* * *} \\
(0.11)\end{array}$ & $\begin{array}{l}0.163 \\
(0.28)\end{array}$ & $\begin{array}{l}0.288^{* * *} \\
(0.11)\end{array}$ \\
\hline Plot size (ha) & $\begin{array}{l}-0.016 \\
(0.052)\end{array}$ & $\begin{array}{l}0.012 \\
(0.026)\end{array}$ & $\begin{array}{l}0.023 \\
(0.034)\end{array}$ & $\begin{array}{l}-0.202 \\
(0.150)\end{array}$ \\
\hline$(\text { Plot size })^{\wedge} 2$ & $\begin{array}{l}0.001 \\
(0.001)\end{array}$ & $\begin{array}{l}0.000 \\
(0.000)\end{array}$ & $\begin{array}{l}-0.000 \\
(0.000)\end{array}$ & $\begin{array}{l}0.007 \\
(0.016)\end{array}$ \\
\hline$(\text { Plot size })^{\wedge} 3$ & $\begin{array}{l}0.000 \\
(0.000)\end{array}$ & $\begin{array}{l}0.000 \\
(0.000)\end{array}$ & $\begin{array}{l}0.000 \\
(0.000)\end{array}$ & $\begin{array}{l}-0.000 \\
(0.000)\end{array}$ \\
\hline Plot land quality index (1-10) & $\begin{array}{l}-0.266 \\
(0.220)\end{array}$ & $\begin{array}{l}0.088 \\
(0.060)\end{array}$ & $\begin{array}{l}-0.297 \\
(0.23)\end{array}$ & $\begin{array}{l}0.595^{* * *} \\
(0.10)\end{array}$ \\
\hline Plot location (km to house) & $\begin{array}{l}-0.082 \\
(0.21)\end{array}$ & $\begin{array}{l}0.240^{* *} \\
(0.10)\end{array}$ & $\begin{array}{l}0.213^{*} \\
(0.12)\end{array}$ & $\begin{array}{l}0.272^{* *} \\
(0.11)\end{array}$ \\
\hline $\begin{array}{l}\text { Without controlling for plot charc } \\
\text { \# forced co-owners }\end{array}$ & $\begin{array}{l}-0.204 \\
(0.34)\end{array}$ & $\begin{array}{l}0.437^{* * *} \\
(0.11)\end{array}$ & $\begin{array}{l}0.130 \\
(0.30)\end{array}$ & $\begin{array}{l}0.392^{* * *} \\
(0.13)\end{array}$ \\
\hline Observations & 3140 & 3140 & 3140 & 3140 \\
\hline
\end{tabular}

Note: Only plots directly obtained through restitution. All regressions control for household characteristics (land ownership (ha), education and age household head, square of education and age household head, and regional fixed effects), and only include plots obtained directly through restitution. Robust standard errors in parentheses, corrected for clustering at community level. All regressions account for sampling weights.

$p<0.1$.

*** $p<0.05$.

$* * * \quad p<0.01$

sults on forced co-ownership are robust to the exclusion of plot-level control variables, providing further support for the identification.

The results hence confirm that plots in forced co-ownership are much more likely to be left in one of the default options. ${ }^{22}$ The point estimates of the coefficients of the two default options (renting to cooperative and land abandonment) in the multinomial regressions are both significant and similar in magnitude. The empirical findings in the multinomial regressions hence support the grouping of these two allocations in the binary choice model.

\subsection{Identification test using other baseline plot characteristics}

To further motivate the empirical strategy, it would be ideal to show that baseline characteristics of the plots above and below the cut-off line are similar. However, given that the data was collected in 2003, very few plot or household characteristics can be argued to reflect baseline values. However the variables measuring land quality and location both capture important characteristics that were, just as plot size, predetermined by the restitution process, and are unlikely to have changed since restitution. We therefore use the same specification as before but with plot quality and location as dependent variable, to show that we do not find a significant discontinuity at the cut-off. The results, presented in Table 7 and using the same samples as before, show that there are no significant discontinuities for these variables. Moreover the point estimates are very small. Specifically, the point estimate of -0.12 in the first column corresponds to 0.06 of a standard deviation of the land quality index, while the point estimate of 0.02 in column 4 corresponds to 0.002 of a standard deviation of distance from plot to house. The estimations hence do not identify an impact on variables on which no impact is to be expected, providing further support for the identification strategy.

\section{The effect of co-ownership on default plot allocation and welfare}

Section 5 focused on the issue of forced co-ownership per se. Yet, the overall impact of co-ownership, whether forced or chosen is of interest too. In this section, we hence proceed with identifying the effect of co-ownership more broadly, taking advantage of the frequency of forced co-ownership in our sample. We use the exogenous variation in forced co-ownership that results from the minimum plot size legislation as an instrument for co-ownership. We also discuss the efficiency implications of the findings of plot allocation. We then turn to the welfare implications, and estimate the impact of co-ownership on household welfare, using a similar IV strategy.

\footnotetext{
${ }^{22}$ Similar results are obtained when restricting the sample to plots around the cut-off, when using a cubic of plot size/number of co-owners instead of plot size, and when using the dummy variable indicating non-divisibility by law instead of the number of forced co-owners.
} 
Table 7

OLS analysis of discontinuity for other plot characteristics (with household-level fixed effects).

\begin{tabular}{|c|c|c|c|c|c|c|}
\hline & \multicolumn{3}{|c|}{ Plot quality } & \multicolumn{3}{|c|}{ Plot location } \\
\hline & $(1)$ & $(2)$ & (3) & $(4)$ & $(5)$ & (6) \\
\hline Non-divisible by law & $\begin{array}{l}-0.122 \\
(0.248)\end{array}$ & $\begin{array}{l}0.046 \\
(0.207)\end{array}$ & $\begin{array}{l}0.006 \\
(0.112)\end{array}$ & $\begin{array}{l}0.020 \\
(0.287)\end{array}$ & $\begin{array}{l}0.254 \\
(0.231)\end{array}$ & $\begin{array}{l}0.382 \\
(0.231)\end{array}$ \\
\hline Plot size (ha) & $\begin{array}{l}-0.665 \\
(0.605)\end{array}$ & $\begin{array}{l}-0.409 \\
(0.428)\end{array}$ & $\begin{array}{l}-0.050^{* * * *} \\
(0.017)\end{array}$ & $\begin{array}{l}1.741 \\
(1.744)\end{array}$ & $\begin{array}{l}0.514 \\
(0.699)\end{array}$ & $\begin{array}{l}0.183^{* * *} \\
(0.043)\end{array}$ \\
\hline$(\text { Plot size })^{\wedge} 2$ & $\begin{array}{l}0.092 \\
(0.082)\end{array}$ & $\begin{array}{l}0.049 \\
(0.060)\end{array}$ & $\begin{array}{l}0.000^{* *} \\
(0000)\end{array}$ & $\begin{array}{l}-0.205 \\
(0.233)\end{array}$ & $\begin{array}{l}0.028 \\
(0.147)\end{array}$ & $\begin{array}{l}-0.002^{* * *} \\
(0.000)\end{array}$ \\
\hline$(\text { Plot size })^{\wedge} 3$ & $\begin{array}{l}-0.004 \\
(0.004)\end{array}$ & $\begin{array}{l}-0.002 \\
(0.003)\end{array}$ & $\begin{array}{l}-0.000^{* * *} \\
(0.000)\end{array}$ & $\begin{array}{l}0.007 \\
(0.009)\end{array}$ & $\begin{array}{l}-0.003 \\
(0.007)\end{array}$ & $\begin{array}{l}0.000^{* * *} \\
(0.000)\end{array}$ \\
\hline Plot location (km to house) & $\begin{array}{l}-0.023 \\
(0.024)\end{array}$ & $\begin{array}{l}0.003 \\
(0.016)\end{array}$ & $\begin{array}{l}0.005 \\
(0.006)\end{array}$ & & & \\
\hline $\begin{array}{l}\text { Plot land quality index }(1-10) \\
(1=\text { best; } 10=\text { worst })\end{array}$ & & & & $\begin{array}{l}-0.080 \\
(0.073)\end{array}$ & $\begin{array}{l}0.014 \\
(0.077)\end{array}$ & $\begin{array}{l}0.050 \\
(0.099)\end{array}$ \\
\hline Observations & 332 & 670 & 1903 & 332 & 670 & 1903 \\
\hline$R$-squared & 0.400 & 0.394 & 0.337 & 0.213 & 0.421 & 0.572 \\
\hline Number of forced co-owners & $\begin{array}{l}-0.065 \\
(0.173)\end{array}$ & $\begin{array}{l}-0.085 \\
(0.071)\end{array}$ & $\begin{array}{l}0.003 \\
(0.021)\end{array}$ & $\begin{array}{l}0.048 \\
(0.085)\end{array}$ & $\begin{array}{l}-0.088 \\
(0.268)\end{array}$ & $\begin{array}{l}0.017 \\
(0.036)\end{array}$ \\
\hline Plot size (ha) & $\begin{array}{l}-0.698 \\
(0.620)\end{array}$ & $\begin{array}{l}-0.410 \\
(0.410)\end{array}$ & $\begin{array}{l}-0050^{* * *} \\
(0017)\end{array}$ & $\begin{array}{l}1.760 \\
(1.725)\end{array}$ & $\begin{array}{l}0.532 \\
(0.715)\end{array}$ & $\begin{array}{l}0.174^{* * * *} \\
(0.042)\end{array}$ \\
\hline$(\text { Plot size })^{\wedge} 2$ & $\begin{array}{l}0.099 \\
(0.086)\end{array}$ & $\begin{array}{l}0.053 \\
(0.055)\end{array}$ & $\begin{array}{l}0.000^{* *} \\
(0.000)\end{array}$ & $\begin{array}{l}-0.209 \\
(0.230)\end{array}$ & $\begin{array}{l}0.029 \\
(0.160)\end{array}$ & $\begin{array}{l}-0.002^{* * *} \\
(0.000)\end{array}$ \\
\hline$(\text { Plot size })^{\wedge} 3$ & $\begin{array}{l}-0.005 \\
(0.004)\end{array}$ & $\begin{array}{l}-0.002 \\
(0.002)\end{array}$ & $\begin{array}{l}-0.000^{* * *} \\
(0.000)\end{array}$ & $\begin{array}{l}0.007 \\
(0.009)\end{array}$ & $\begin{array}{l}-0.003 \\
(0.008)\end{array}$ & $\begin{array}{l}0.000^{* * * *} \\
0.000\end{array}$ \\
\hline Plot location (km to house) & $\begin{array}{l}-0.023 \\
(0.024)\end{array}$ & $\begin{array}{l}0.003 \\
(0.016)\end{array}$ & $\begin{array}{l}0.005 \\
(0.006)\end{array}$ & & & \\
\hline $\begin{array}{l}\text { Plot land quality index }(1-10) \\
(1=\text { best; } 10=\text { worst })\end{array}$ & & & & $\begin{array}{l}-0.079 \\
(0.073)\end{array}$ & $\begin{array}{l}0.013 \\
(0.074)\end{array}$ & $\begin{array}{l}0.051 \\
(0.099)\end{array}$ \\
\hline Observations & 332 & 670 & 1903 & 332 & 670 & 1903 \\
\hline$R$-squared & 0.400 & 0.395 & 0.337 & 0.214 & 0.420 & 0.572 \\
\hline
\end{tabular}

Note: Sample in columns 1 and 4 restricted to plots around discontinuity point with 0.15 ha $<$ plot size/\# co-owners $<0.45$ ha; and in columns 2 and 5 restricted to plots with 0.1 ha < plot size/\# co-owners $<0.5$ ha. All regressions include household fixed effects and only include households with variation in plot allocation and only plots obtained directly through restitution. Robust standard errors in parentheses, corrected for clustering at community level. All regressions account for sampling weights.

${ }^{*} p<0.1$.

${ }^{* *} p<0.05$.

*** $p<0.01$.

\subsection{Plot allocation and efficiency}

Turning to the estimates of Eq. (5), the second stage results in the top panel of Table 8 show that the number of co-owners has a significant impact on plot allocation. In particular, the IV estimates in columns 2 and 3 show that increasing the number of co-owners with 1 increases the probability of the default option with $8-16 \%$ points. The first stage results in the bottom panel of Table 8 show, not surprisingly, that the number of forced co-owners is a very strong instrument for the actual number of co-owners, and the dummy indicating the non-divisibility is also relatively strong ( $F$-value of 36 ). Comparing the IV results with the naïve OLS estimates in column 1 indicates that not accounting for the endogeneity of co-ownership leads to an underestimation. The results on the full sample of plots are similar, though somewhat less significant (as in the reduced form estimates in Table 5).

Other papers (such as Besley, 1995) have shown that effects of property rights are often region-specific. Table 9 therefore presents results by region. We find similar and significant effects in the North-Central and the South-Central region. As before, the point estimates of the IV are larger than those of the naïve OLS. The point estimates for the North-East region, which are substantially higher, should be interpreted with caution given the very low number of observations. Households in this region own less plots on average and therefore there are relatively few observations with within-household variation for that region. Overall, the results by region confirm the earlier findings.

The results hence establish that land in co-ownership is more likely to be either left in the cooperative or abandoned. While the data do not allow analyzing the efficiency consequences of these findings directly, there are a number of reasons to believe that this may be inefficient.

First, land abandonment likely indicates an inefficient allocation, as leaving land fallow for soil recovery reasons is not a common practice in Bulgaria. In particular, as the regressions control for land quality, the results imply that forced co-ownership leads to abandonment of otherwise productive land. Indeed, among plots with more than average land quality, plots are more than twice as likely to be abandoned when they are in forced co-ownership than when they are not.

Second, with regard to the allocation of land to cooperatives, the literature has emphasized a number of theoretical reasons for why this could lead to inefficiencies. Individual workers' incentives to free ride on the labor efforts of others 
Table 8

Impact of co-ownership on the probability of renting to cooperatives or leaving land abandoned (with household fixed effects).

\begin{tabular}{|c|c|c|c|c|c|c|}
\hline & \multicolumn{3}{|c|}{ Only plots directly obtained through restitution } & \multicolumn{3}{|l|}{ All plots } \\
\hline & $(1)$ & $(2)$ & $(3)$ & $(4)$ & $(5)$ & (6) \\
\hline & Naive OLS & IV & IV & Naive OLS & IV & IV \\
\hline \multicolumn{7}{|l|}{ Second stage } \\
\hline Number of co-owners & $\begin{array}{l}0.071^{* * * *} \\
(0.016)\end{array}$ & $\begin{array}{l}0.156^{*} \\
(0.078)\end{array}$ & $\begin{array}{l}0.082^{* * *} \\
(0.012)\end{array}$ & $\begin{array}{l}0.059^{* * *} \\
(0.013)\end{array}$ & $\begin{array}{l}0.112 \\
(0.084)\end{array}$ & $\begin{array}{l}0.075^{\text {****}} \\
(0.012)\end{array}$ \\
\hline Plot characteristics & Yes & Yes & Yes & Yes & Yes & Yes \\
\hline$R$-squared & 0.35 & & & 0.36 & & \\
\hline \multicolumn{7}{|l|}{ First stage } \\
\hline Non-divisible by law & & $\begin{array}{l}1.220^{* * *} \\
(0.204)\end{array}$ & & & $\begin{array}{l}1.276^{* * *} \\
(0.198)\end{array}$ & \\
\hline Number of forced co-owners & & & $\begin{array}{l}0.904^{* * *} \\
(0.047)\end{array}$ & & & $\begin{array}{l}0.903^{\text {**** }} \\
(0.049)\end{array}$ \\
\hline Plot characteristics & & Yes & Yes & & Yes & Yes \\
\hline$R$-squared & & 0.77 & 0.98 & & 0.76 & 0.96 \\
\hline Observations & 1903 & 1903 & 1903 & 2198 & 2198 & 2198 \\
\hline
\end{tabular}

Note: All regressions include household lived fixed effects and only include households with variation in plot allocation, and only plots obtained directly through restitution. Plot characteristics included plot size, plot size ${ }^{\wedge}$, plot size^ 3 , plot quality index and plot location (distance to plot). Robust standard error in parentheses, corrected for clustering at community level. All regressions account for sampling weights.

${ }^{*} p<0.1$.

** $p<0.05$.

**** $p<0.01$.

Table 9

Impact of co-ownership on the probability of renting to cooperatives or leaving land abandoned by region (with household fixed effects).

\begin{tabular}{|c|c|c|c|c|c|c|}
\hline & $\begin{array}{l}\text { (1) } \\
\text { Naive OLS }\end{array}$ & $\begin{array}{l}(2) \\
\text { IV }\end{array}$ & $\begin{array}{l}(3) \\
\text { Naive OLS }\end{array}$ & $\begin{array}{l}(4) \\
\text { IV }\end{array}$ & $\begin{array}{l}(5) \\
\text { Naive OLS }\end{array}$ & $\begin{array}{l}(6) \\
\text { IV }\end{array}$ \\
\hline \multicolumn{7}{|l|}{ Second stage } \\
\hline Number of co-owners & $\begin{array}{l}0.032^{* *} \\
(0.008)\end{array}$ & $\begin{array}{l}0.054^{* *} \\
(0.017)\end{array}$ & $\begin{array}{l}0.150 \\
(0.300)\end{array}$ & $\begin{array}{l}0.615^{* * *} \\
(0.028)\end{array}$ & $\begin{array}{l}0.075^{* * *} \\
(0.018)\end{array}$ & $\begin{array}{l}0.084^{\text {**** }} \\
(0.013)\end{array}$ \\
\hline Plot characteristics & Yes & Yes & Yes & Yes & Yes & Yes \\
\hline$R$-squared & 0.48 & & 0.42 & & 0.33 & \\
\hline \multicolumn{7}{|l|}{ First-stage } \\
\hline Number of forced co-owners & & $\begin{array}{l}0.723^{* * *} \\
(0.111)\end{array}$ & & $\begin{array}{l}0.952^{* * * *} \\
(0.016)\end{array}$ & & $\begin{array}{l}0.925^{\text {*** }} \\
(0.035)\end{array}$ \\
\hline Plot characteristics & & Yes & & Yes & & Yes \\
\hline$R$-squared & & 0.95 & & 0.91 & & 0.98 \\
\hline Observations & 710 & 710 & 32 & 32 & 1161 & 1161 \\
\hline
\end{tabular}

Note: Only plots directly obtained through restitution. All regression include household fixed effects and only include households with variation in plot allocation, and only plots obtained directly through restitution. Plot characteristics included plot size, plot size^ 2 , plot size^ 3 , plot quality index and plot location (distance to plot). Robust standard errors ir parentheses, corrected for clustering at community level. All regressions account for sampling weights.

${ }^{*} p<0.1$.

** $p<0.05$.

*** $p<0.01$.

imply the need for more costly monitoring (Carter, 1984). The organizational structure of the cooperative, where each member has one vote, also does not facilitate possible efficiency-enhancing employment reductions (Schmitt, 1993). Moreover, the management functions of the cooperatives were, as of 2003, very often still occupied by the former managers of the collectives, who were used to work under soft budget constraints. All this then would suggest that allocation of land to cooperatives as a result of co-ownership might also imply an efficiency cost. Yet, among empirical studies trying to quantify efficiency differences between the various forms of land users, there appears to be no consensus on whether family farms or larger entities are more efficient (Gorton and Davidova, 2004). Indeed, Allen and Lueck (1998) analyze how depending on the type of agricultural and livestock activities the farms specialize in, as well as the context in which they operate, there are likely to be different moral hazard issues (for which family farms have an advantage) and different potential economies of scales (the advantage of the larger farms). It is therefore important that the results in this paper indicate that co-ownership leads to an under-allocation of land to both households and de novo agricultural companies. These agricultural companies are often of similar size as the cooperatives (see Table 2), and hence should have similar economies (or dis-economies) of scale. At the same time, their incentive structure and decision-making process is generally more conducive to profit-maximizing production and efficient asset allocation, compared to cooperatives (Mathijs and Swinnen, 2001). 


\subsection{Co-ownership and household welfare}

In addition to potential efficiency trade-offs, there are several reasons to believe that misallocation of land to cooperatives and abandonment could substantially affect the owners' welfare. First, land abandonment implies that a household is not receiving any returns to that land asset. Second, households' returns from renting to cooperatives might be limited because these large farm organizations have substantial market power in local or regional land markets. Indeed, evidence from a number of transition countries suggests that cooperatives often offer lower prices and worse contract terms than individual farms. For example, in the Czech Republic and Slovakia land rents paid by cooperative farms were only between $20 \%$ and $50 \%$ of the rents paid by family farms in the past years. Other survey evidence has shown that cooperative farms generally pay their rents in kind, while family farms were much more likely to pay cash or mixed cash/in-kind, both in Bulgaria and in other Eastern European countries (Vranken and Swinnen, 2006; World Bank, 2006). ${ }^{23}$

We now turn to analyzing the relationship between household welfare and land co-ownership directly. One way of doing this would be to compare welfare of households who single own a plot slightly less than 0.3 ha, with households who coown a plot slightly more than 0.3 ha. However households in the sample own a large number of plots (about 5 on average) implying that they might own both plots that are and that are not divisible. We therefore estimate instead the impact of the total area in co-ownership, and instrument this with two variables that capture the legally forced co-ownership. In particular, the co-owned area is instrumented with a dummy variable that equals one if the household owns at least one plot that cannot be divided according to the minimum plot size law and with a variable measuring the area that is in legally forced coownership.

Table 10 shows how the welfare index relates to land co-ownership, after controlling for exogenous household characteristics, both when considering all households, and when only considering households with land obtained directly through restitution. Besides the total amount of land owned by the household, a separate variable indicating the amount of land coowned is included on the right hand side. ${ }^{24}$ In column 2, the co-owned area is instrumented with the dummy variable that equals one if the household owns at least one plot that cannot be divided according to the minimum plot size law. In column 3 , the area that is in legally forced co-ownership is added as an additional instrument for the total co-owned area. Control variables for households' human capital (education and age of the household head) and regional fixed effects are added. The first column of Table 10 shows the OLS regression results for comparison. Before discussing the results, we note that these results on welfare are more tentative, as the unit of observation is now the household, and we can hence no longer control for any unobserved household level characteristics. ${ }^{25}$ Moreover, the results rely on aggregation of plots of all different sizes, and not just plots around the discontinuity. This is necessary given the large number of plots owned by households. The plot-level findings showed that including plots that are farther away from the cut-off decreased the magnitude of the impacts, suggesting that by including those in the household level analysis, we might bias the results towards zero.

The first stage regression results in the lower panel of Table 10 show that the instruments are strong. The 2nd stage results in the top panel indicate that land co-ownership is negatively related to household welfare, holding total land ownership and other household characteristics constant. The coefficients obtained in the IV are very similar for the two definitions of the instrument, and the point estimates of the IV are about twice as large as the OLS results. This indicates the importance of correcting for the endogeneity of co-ownership. Adding the coefficients of total land ownership and of the area in co-ownership, the estimated returns to land for land in co-ownership are in fact not significantly different from zero. ${ }^{26}$ Hence while ownership of land by single owners is related to significantly higher household welfare, as one would expect, this is not true for land that is held in co-ownership. These results suggest that land co-ownership is related to substantial welfare losses.

\section{Conclusion}

This paper analyzes the impact of land property rights imperfections on asset allocation and the relationship with household welfare by studying co-ownership of land using micro-evidence from Bulgaria. While land titles are distributed and land plots clearly defined and delineated, an important property rights problem that affects land allocation exists under the form of joint ownership. Households' land ownership in Bulgaria is mostly determined by the restitution process from the beginning of the 1990s, and by a law on minimum plot size. The law implies forced co-ownership for plots that would be below the minimum size if they were to be divided among all the legal co-owners. This paper takes advantage of the artificial cut-off resulting from the law on minimum plot size to identify the effect of co-ownership on land allocation decisions and household welfare.

The estimated local average treatment effects show that plots in forced co-ownership are $28-40 \%$ points more likely to be left abandoned or used by large-scale cooperatives, which are generally considered less efficient farm organizations. Vice

\footnotetext{
${ }^{23}$ The lower rental prices and contract terms designed in their favor might help explain why the cooperatives, even if they may be less efficient users of the land, can survive.

${ }^{24}$ For co-owned plots, the amount of land owned by a household is obtained by dividing plot size of each co-owned plot with the number of co-owners. When calculating the total land ownership of a household, we sum the plot size of the co-owned plots divided by the number of co-owners for each plot, and add to that the plot size of the single-owned plots.

25 Plot-level characteristics are also not included because welfare is analyzed at the household level.

${ }^{26}$ The estimated sum is negative, but $t$-tests confirm that the sum is not significantly different from zero ( $P$-values between 0.45 and 0.93 ).
} 
OLS and IV regression: relationship between co-ownership and household welfare.

\begin{tabular}{|c|c|c|c|c|c|c|}
\hline & \multicolumn{3}{|c|}{ All household } & \multicolumn{3}{|c|}{$\begin{array}{l}\text { Only households with land obtained } \\
\text { directly through restitution }\end{array}$} \\
\hline & $\begin{array}{l}(1) \\
\text { Naive OLS }\end{array}$ & $\begin{array}{l}(2) \\
\text { IV }\end{array}$ & $\begin{array}{l}(3) \\
\text { IV }\end{array}$ & $\begin{array}{l}(1) \\
\text { Naive OLS }\end{array}$ & $\begin{array}{l}(2) \\
\text { IV }\end{array}$ & $\begin{array}{l}(3) \\
\text { IV }\end{array}$ \\
\hline \multicolumn{7}{|l|}{ Second stage regression } \\
\hline Total land ownership & $\begin{array}{l}0.019^{* * *} \\
(0.003)\end{array}$ & $\begin{array}{l}0.019^{* * *} \\
(0.003)\end{array}$ & $\begin{array}{l}0.019^{* * *} \\
(0.003)\end{array}$ & $\begin{array}{l}0.021^{* * *} \\
(0.003)\end{array}$ & $\begin{array}{l}0.021^{* * *} \\
(0.003)\end{array}$ & $\begin{array}{l}0.021^{* * *} \\
(0.003)\end{array}$ \\
\hline Area in co-ownership & $\begin{array}{l}-0.014 \\
(0.010)\end{array}$ & $\begin{array}{l}-0.030^{* *} \\
(0.013)\end{array}$ & $\begin{array}{l}-0.025^{* *} \\
(0.012)\end{array}$ & $\begin{array}{l}-0.012 \\
(0.010)\end{array}$ & $\begin{array}{l}-0.026^{*} \\
(0.013)\end{array}$ & $\begin{array}{l}-0.023^{*} \\
(0.012)\end{array}$ \\
\hline$p$-value of testing $H_{0}$ : total land ownership + area in co-ownership $=0$ & 0.68 & 0.45 & 0.61 & 0.42 & 0.74 & 0.93 \\
\hline$R$-squared & 0.24 & & & 0.25 & & \\
\hline First stage regression & & \multicolumn{2}{|c|}{ Area in co-ownership } & & \multicolumn{2}{|c|}{ Area in co-ownership } \\
\hline Total land ownership & & $\begin{array}{l}0.065^{* * *} \\
(0.019)\end{array}$ & $\begin{array}{l}0.058^{* * *} \\
(0.013)\end{array}$ & & $\begin{array}{l}0.065^{* * *} \\
(0.019)\end{array}$ & $\begin{array}{l}0.061^{* * *} \\
(0.014)\end{array}$ \\
\hline Owns plot that cannot be divided by law & & $\begin{array}{l}14.18^{* * *} \\
(1.42)\end{array}$ & $\begin{array}{l}7.760^{* * *} \\
(2.01)\end{array}$ & & $\begin{array}{l}14.65^{\text {*** }} \\
1.270\end{array}$ & $\begin{array}{l}8.814^{* * * *} \\
(2.140)\end{array}$ \\
\hline Area in forced co-ownership & & & $\begin{array}{l}0.869^{* * *} \\
(0.21)\end{array}$ & & & $\begin{array}{l}0.772^{* *} \\
(0.220)\end{array}$ \\
\hline$R$-squared & & 0.49 & 0.58 & & 0.51 & 0.57 \\
\hline F-value instruments & & 100 & 163 & & 132 & 161 \\
\hline Observations & 697 & 697 & 697 & 558 & 558 & 558 \\
\hline
\end{tabular}

Note: Land area expressed in decares ( 10 decares $=1 \mathrm{ha}$ ). Control variables in all regressions include age and gender of household head, and regional fixed effects. The dependent variable is a welfare index based on ownership of key assets (first principal component). Regression results account for sampling weights. Robust standard errors in parentheses, corrected for clustering at the community level.

${ }^{*} p<0.1$.

*** $p<0.05$.

*** $p<0.01$

versa, they are less likely to be used by individual household farms or de novo agricultural companies. And inefficient allocations are more likely for plots with a larger number of co-owners, suggesting larger decision-making problems as the number of co-owners increases. On average, for each additional co-owner, the likelihood that a plot of land is used by cooperatives or is left abandoned is estimated to be $8-16 \%$ points higher. The results are consistent with the possible role of high transaction costs and costly decision-making for plots in co-ownership, but could also be due to collective action problems. In particular, free riding on the efforts of others to optimize the plot allocation might become more likely with many owners. Independent of the underlying mechanism, the results suggest that the negative allocation effects could be mitigated when monitoring and coordination costs are low. The analysis in this paper further suggests that land co-ownership is related to substantial household welfare losses.

These results were obtained with data collected relatively shortly after the restitution process was completed, during economically volatile times and prior to EU accession. It is possible that alternative transfer mechanisms to circumvent the minimum plot size legislation developed in subsequent years. As such, there might be a transitory component to the issue of forced co-ownership highlighted in this paper. That said, anecdotal evidence suggest that co-ownership problems were still affecting the land markets in 2010 (Swinnen and Vranken, 2010).

Overall, the evidence in this paper indicates that property rights imperfections can remain a serious constraint, even after a massive land privatization process aimed at restituting complete property rights. As such, it sheds new light on the different dimensions of property rights that can be important for economic growth and development. In particular, historical ownership and legal constraints can reduce effective decision-making. This can result in sub-optimal land allocation even after complete land titles have been established.

\section{Acknowledgments}

The paper benefitted a lot from the detailed comments by a referee and the editor. The authors are grateful to seminar participants in Washington DC (ABCDE), Kent (EAAE), Cornell University (NEUDC) and Leuven for comments on earlier versions of this paper. This project was supported by the University of Leuven (KUL Research Grant OT, EF and Methusalem projects), the FAO (Development of Land Rental Markets in Bulgaria and Macedonia project), and the Fund for Scientific Research (FWO) (Project G.0088.03). The views in this paper are those of the authors and not necessarily reflect those of organizations they are associated with or those that funded the research.

\section{References}

Acemoglu, Daron, Johnson, Simon, 2005. Unbundling institutions. The Journal of Political Economy (113), 949-995.

Acemoglu, Daron, Johnson, Simon, Robinson, James, 2001. The colonial origins of comparative development: an empirical investigation. American Economic Review (91), 1369-1401. 
Allen, Douglas W., Lueck, Dean, 1998. The nature of the farm. Journal of Law and Economics XLI (October), $343-386$.

Angrist, Joshua, Lavy, Victor, 1999. Using Maimonides rule to estimate the effect of class size on scholastic achievement. Quarterly Journal of Economics 114 (20), 533-575.

Besley, Timothy, 1995. Property rights and investment incentives: theory and evidence from Ghana. The Journal of Political Economy 103 (5), $903-937$.

Bilsen, Valentijn, Konings, Jozef, 1998. Job creation, job destruction, and employment growth of newly established firms in transition countries: survey evidence from Bulgaria, Hungary, and Romania. Journal of Comparative Economics 26 (3), 429-445.

Blarel, Benoit, Peter, Hazell, Frank, Place, John, Quiggin, 1992. The economics of farm fragmentation: evidence from Ghana and Rwanda. The World Bank Economic Review 6 (20), 233-254.

Boucher, Steve, Bradford, Barham, Michael, Carter, 2005. The impact of market-friendly reforms on credit and land markets in Honduras and Nicaragua. World Development 33 (1), 107-128.

Carter, Michael R., 1984. Resource allocation and use under collective rights and labor management in Peruvian coastal agriculture. Economic Journal 94 (376), 826-846.

Carter, Michael R., Olinto, Pedro, 2003. Getting institutions "right" for whom? Credit constraints and the impact of property rights on the quantity and composition of investment. American Journal of Agricultural Economics 85 (1), 173-186.

Conning, Jonathan, Robinson, James, 2007. Property rights and the political organization of agriculture. Journal of Development Economics 82, $416-447$.

Dale, Peter, Richard Baldwin, 2000. Emerging Land Markets in Central and Eastern Europe. In: Csaki, Lerman (Eds.), Structural Change in the Farming Sectors in Central and Eastern Europe, WB Technical Paper, No. 465.

Deaton, James, 2006. Intestate Succession, Property and the Persistence of Poverty: Implications for the Appalachian Region. University of Guelph, Mimeo.

Field, Erica, 2005. Property rights and investment in urban slums. Journal of the European Economic Association 3 (2-3), 279-290.

Field, Erica, 2007. Entitled to work: urban property rights and the labor supply in Peru. Quarterly Journal of Economics 4 (122), 1561-1602.

Finan, Frederico, Elisabeth, Sadoulet, Alain, de Janvry, 2005. Measuring the poverty reduction potential of land in Mexico. Journal of Development Economics 77 (1), 27-51.

Galiani, Sebastian, Schargrodsky, Ernesto, 2007. Property Rights for the Poor: Effects of Land Titling. Universidad Torcuato di Tella, Buenos Aires, Mimeo.

Glaeser, Edward, Simon, Johnson, Andrei, Shleifer, 2001. Coase versus the Coasians. Quarterly Journal of Economics 116 (3), $853-899$.

Goldstein, Markus, Udry, Chris, 2008. The profits of power: land rights and agricultural investment in Ghana. The Journal of Political Economy 116 (6), $981-$ 1022.

Gorton, Matthew, Davidova, Sofia, 2004. Farm productivity and efficiency in the CEE applicant countries: a synthesis of results. Agricultural Economics 30 (1), 1-16.

Grover, Richard, 2006. European Union Accession and Land Tenure Data in Central and Eastern Europe. FAO Land Tenure Policy Series 1.

Hart, Oliver, 1995. Firms, Contracts, and Financial Structure. Oxford University Press, Oxford.

Holderness, Clifford, 2003. Joint ownership and alienability. International Review of Law and Economics 23 (1), 75-100.

Jacoby, Hanan, Guo, Li, Scott, Rozelle, 2002. Hazards of expropriation: tenure insecurity and investment in rural China. American Economic Review 92 (5), $1420-1447$.

Konings, Jozef, Patrick, Van Cayseele, Frederic, Warzynski, 2005. The effects of privatization and competitive pressure on firms' price-cost margins: microevidence from emerging economies. Review of Economics and Statistics 87 (1), 124-134

Kopeva, Diana., Noev, Nivelin., Evtimov, Vladimir., 2002. Land Fragmentation and Consolidation in the Agricultural Sector. A Case Study from Bulgaria. FAO Working Paper.

Kopeva, Diana, Madjarova, Svetla I., Peneva, Mariya, Harizanova, Hristina S, 2010. Review of the Transitional Restrictions Maintained by Bulgaria and Romania with Regard to the Acquisition of Agricultural Real Estate: Bulgarian Country Report. Report Prepared for CEPS.

Lanjouw, Jean, Levy, Philip, 2002. Untitled: a study of formal and informal property rights in Urban Ecuador. The Economic Journal 112 (482), 986-1019.

Macours, Karen, Alain, de Janvry, Elisabeth, Sadoulet, 2010. Insecurity of property rights and social matching in the tenancy market. European Economic Review 54, 880-899.

Manski, Charles F., Lerman, Steven, 1977. The estimation of choice probabilities from choice-based samples. Econometrica 45, $1977-1988$.

Mathijs, Erik, Swinnen, Johan F.M., 2001. Production organization and efficiency during transition: an empirical analysis of East German agriculture. Review of Economics and Statistics 83 (1), 100-107.

Mearns, Robin, 1999. Access to Land in Rural India. World Bank Policy Research Working Paper 2123, Washington, DC

Ministry of Agriculture and Food of the Republic of Bulgaria, 2009. Bulgarian Rural Development Programme 2007-2013. <http://www.mzh.government. bg/Article.aspx?lang=2\&rmid=432\&id $=432 \& \operatorname{lmid}=0>$.

Mitchell, Thomas, 2001. From reconstruction to deconstruction: undermining black landownership, political independence, and community through partition sales of tenancies in common. Northwestern Law Review 95 (2), 505-580.

Nickell, Stephen, 1996. Competition and corporate performance. Journal of Political Economy 104 (4), 724-746.

Pitt, Mark, Khandker, Sahidur, 1988. The impact of group-based credit programs on poor households in Bangladesh: does the gender of participants matter? The Journal of Political Economy 106, 958-996.

Porter, Jack, 1999. Semiparametric Estimation of Regression Discontinuity Models. Harvard University, Mimeo.

Roland, Gerard, 2002. The political economy of transition. Journal of Economic Perspectives 16 (1), 29-50.

Schmitt, Gunter., 1993. Why decollectivisation of agriculture in socialist countries has failed: a transaction cost approach. In: Csaki, C., Kislev, Y. (Eds.), Agriculture Cooperatives in Transition. Westview Press, Boulder, pp. 143-159.

Shoemaker, Jessica, 2003. Like snow in the spring time: allotment, fractionation, and the Indian Land Tenure Problem. Wisconsin Law Review, 733-788.

Swinnen, Johan, Vranken, Liesbet, 2010. Review of the Transitional Restrictions Maintained by Bulgaria and Romania with Regard to the Acquisition of Agricultural Real Estate, Report Prepared for the European Commission, Centre for European Policy Studies, Brussels.

Swinnen, Johan, Vranken, Liesbet, Stanley, Victoria, 2006. Emerging Challenges of Land Markets. A Review of the Available Evidence for the Europe and Central Asia Region. Chief Economist's Regional Working Paper Series Infrastructure Department (ECSIE), vol. 1, no. 4. The World Bank, Washington, DC.

Van der Klaauw, Wilbert, 2002. Estimating the effect of financial aid offers on college enrollment: a regression-discontinuity approach. International Economic Review 43 (4), 1249-1287.

Vranken, Liesbet, Swinnen, Johan, 2006. Land rental markets in transition: theory and evidence from Hungary. World Development 34 (3), 481-500.

World Bank, 2006. Agricultural Land Rental Markets in Europe and Central Asia. Developments, Constraints, and Implications, World Bank Report, Washington, DC. 